\title{
Bobot Relatif Saluran Pencernaan Ayam Broiler yang Diberi Tambahan Air Rebusan Kunyit dalam Air Minum
}

\section{Relative Weight of Broiler Digestive Tract by Addition of Turmeric Water in Drinking Water}

\author{
D. D. R. Pertiwi", R. Murwani dan T. Yudiarti \\ Fakultas Peternakan dan Pertanian, Universitas Diponegoro, Semarang, 50275 \\ *E-mail: debodeborah8@gmail.com
}

(Diterima: 14 Maret 2017; Disetujui: 25 Mei 2017)

\begin{abstract}
ABSTRAK
Penelitian ini bertujuan untuk mengetahui pengaruh penambahan air rebusan kunyit dalam air minum terhadap bobot relatif saluran pencernaan ayam broiler. Ayam broiler umur satu hari (DOC) 200 ekor dengan bobot badan awal rata-rata 41,48 $\pm 0,99$ gram dialokasikan secara acak ke dalam 5 perlakuan dan 5 ulangan, dimana setiap ulangan terdiri 8 ekor. Lima perlakuan tersebut terdiri dari T0 (100\% air minum), T1 (75\% air minum: 25\% air kunyit), T2 (50\% air kunyit: 50\% air minum), T3 (75\% air kunyit: 25\% air minum) dan T4 (100\% air kunyit). Pakan komersial untuk broiler dan air minum perlakuan diberikan secara ad libitum. Parameter yang diamati yaitu bobot relatif dan panjang relatif saluran pencernaan ayam broiler umur 35 hari. Hasil penelitian menunjukkan bahwa penambahan air kunyit dalam air minum tidak berpengaruh nyata $(\mathrm{P}>0,05)$ terhadap bobot hidup ayam broiler, bobot relatif tembolok, proventikulus, usus halus, hati, usus besar, serta panjang relatif jejenum, sekum dan usus besar. Perlakuan tersebut berpengaruh nyata $(\mathrm{P}<0,05)$ terhadap bobot relatif sekum dan pankreas, serta panjang relatif duodenum dan ileum ayam broiler umur 35 hari. Penambahan air rebusan pada taraf 50-100\% menurunkan baik bobot relatif sekum dan pankreas dan panjang relatif duodenum, dan pada taraf $25 \%$ bobot relatif sekum dan pankres dan panjang relatif duodenum dan ileum sama dengan kontrol tanpa pemberian air rebusan kunyit. Dapat disimpulkan bahwa penambahan air rebusan kunyit dalam air minum menurunkan bobot relatif sekum dan pankreas serta panjang relatif duodenum, maka dianjurkan untuk tidak menggunakan air rebusan kunyit dalam air minum.

Kata kunci: suplemen, Curcuma domestica, kurkumin, ternak, ayam broiler
\end{abstract}

\section{ABSTRACT}

The aim of this study was to determine the effect of the addition of turmeric water in drinking water to relative weight of the digestive tract of broiler chickens. Two hundreds day old chicks with an average body weight of $41.48 \pm 0.99$ gram were randomly assigned into 5 treatments and 5 replication, each replicate consisted of 8 birds. The treatments consisted of T0 (100\% drinking water), T1 (75\% drinking water: 25\% turmeric water), T2 (50\% turmeric water: 50\% drinking water), T3 (75\% turmeric water: $25 \%$ drinking water) and T4 (100\% turmeric water). Feed and water were given in free access. The relative weight and relative length of digestive tract were determined at 35 days. The results showed that addition of turmeric water in drinking water had no significant effect $(P>0.05)$ on broiler life weight, relative weight of crop, proventiculus, small intestine, liver, colon, and relative length of jejunum, and colon. However there was significant $(P<0.05)$ effect on the relative weight of the cecum and pancreas, and the relative length of duodenum and ileum. Addition of 50-100\% turmeric water in drinking water lowered relative weight of secum and pancreas, and relative length of duodenum. At 25\% turmeric water the relative weight of secum and pancreas dan relative length of duodenum dan ileum is similar to control group. It can be concluded that addition of turmeric water in drinking water lowered the relative weight and length of several part of digestive tract and it is advisable not to use it.

Keywords: supplement, Curcuma domestica, curcumin, livestock, broiler chicken 


\section{PNDAHULUAN}

Daging ayam broiler merupakan salah satu sumber protein hewani dengan harga yang relatif murah dan berkualitas sehingga banyak permintaan dari masyarakat. Kualitas daging yang baik salah satunya ditentukan oleh faktor pakan, dimana pakan yang diberikan harus berkualitas dan mencukupi kuantitasnya. Upaya untuk meningkatkan efisiensi pakan dan produktivitas ayam broiler salah satunya dengan cara penambahan aditif. Salah satu bahan aditif yang aman digunakan adalah kunyit (Hutabarat et al., 2014). Kunyit merupakan tanaman herbal yang tersebar di seluruh daerah tropis yang bermanfaat karena kandungan senyawa aktifnya yaitu kurkumin dan minyak atsiri. Kunyit mengandung 6,3\% protein, 5,1\% lemak, 3,5\% mineral, 69,4\% karbohidrat dan 13,1\% air (Chattopadhyay et al., 2004; Dono, 2013). Kunyit dengan senyawa aktif kurkumin yang memiliki aktifitas antibakteri dapat berperan terhadap kesehatan dan perkembangan saluran pencernaan ayam broiler.

Saluran pencernaan ayam broiler merupakan organ vital yang memiliki fungsi untuk mencerna pakan dan fungsi imunologis. Penyerapan nutrisi oleh usus dapat berlangsung secara optimal apabila usus dalam keadaan sehat. Kesehatan usus dipengaruhi oleh populasi mikrobia atau bakteri yang hidup di dalamnya. Sifat antibakteri kunyit dapat mengurangi jumlah bakteri patogen, meningkatkan pertumbuhan bakteri yang menguntungkan dalam saluran pencernaan sehingga dapat meningkatkan kesehatan saluran cerna ayam. Selain itu merangsang dinding kantong empedu untuk mengeluarkan cairan empedu sehingga dapat memperlancar metabolisme lemak (Pratikno, 2010). Saluran pencernaan yang sehat ditandai dengan perkembangan berat dan panjang saluran cerna, serta perkembangan vili yang optimal sehingga dapat mengoptimalkan penyerapan nutrisi. Penyerapan nutrisi yang baik dari pakan akan membantu peningkatan bobot hidup ayam (Purwanti, 2008; Murwani,
2010; Mario et al., 2013).

Penelitian ini bertujuan untuk mengkaji bobot relatif saluran pencernaan ayam broiler yang diberi tambahan air kunyit dalam air minum. Manfaat penelitian ini adalah untuk memberikan informasi tentang pemanfaatan air kunyit yang ditambahkan dalam air minum ayam broiler terhadap bobot relatif saluran pencernaan ayam broiler. Hipotesis penelitian ini adalah penambahan air kunyit dalam air minum ayam broiler dapat meningkatkan bobot relatif saluran pencernaan pada ayam broiler.

\section{METODE}

Penelitian dengan judul "Bobot Relatif Saluran Pencernaan Ayam Broiler yang Diberi Tambahan Air Rebusan Kunyit dalam Air Minum" dilaksanakan pada bulan OktoberNovember 2016 di Kandang Unggas, Fakultas Peternakan dan Pertanian, Universitas Diponegoro, Semarang. Pengambilan data bobot relatif saluran pencernaan ayam di Laboratorium Fisiologi dan Biokimia, Fakultas Peternakan dan Pertanian, Universitas Diponegoro, Semarang.

\section{Materi}

Materi yang digunakan pada penelitian yaitu day old chick (DOC) ayam broiler strain Lohmann 202 unsex berjumlah 200 ekor yang berasal dari PT. Japfa Comfeed dengan bobot badan awal rata-rata 41,48 $\pm 0,99$ gram, air minum, kunyit, pakan pabrik PT. Charoen Pokhpand Indonesia, larutan gula jawa untuk air minum DOC yang datang, koran, serta vaksin Newcastle Disease (ND) dan Gumboro. Alat yang digunakan yaitu kelambu dan pagar bambu untuk pembatas antar kandang, tirai plastik sebagai penutup kandang, tempat pakan, tempat minum, termohigrometer untuk mengukur suhu dan kelembaban, sekam, sekop dan disinfektan untuk peralatan sanitasi kandang, pita ukur untuk mengukur panjang, timbangan untuk pakan, bobot badan ayam serta mengukur berat saluran pencernaan dan alat tulis. 
Tabel 1. Kandungan nutrisi pakan fase Starter dan Finisher.

\begin{tabular}{lccccccc}
\hline \multirow{2}{*}{ Periode } & \multicolumn{7}{c}{ Kandungan Nutrisi Pakan (\%) } \\
\cline { 2 - 8 } & KA & Protein & Lemak & SK & Abu & Kalsium & Phospor \\
\hline Starter & 13 & $21-23$ & 5 & 5 & 7 & 0,9 & 0,6 \\
Finisher & 13 & $20-22$ & 5 & 5 & 8 & 1,2 & 1,0 \\
\hline
\end{tabular}

Sumber: PT. Charoen Pokphand Indonesia, 2016.

\section{Metode}

\section{Persiapan Kandang}

Pembersihan kandang dengan fumigasi, disinfektan dan pengapuran, pembuatan kandang litter dengan alas sekam, pemasangan lampu, penyediaan air gula untuk DOC yang baru datang.

\section{Persiapan Air Kunyit}

Kunyit umur 8 bulan diperoleh di wilayah Tembalang dan digunakan bagian empunya. Air kunyit disiapkan dengan cara empu kunyit dibersihkan dari kotoran dengan air mengalir, kemudian diangin-anginkan, ditimbang 10 gram kemudian dimemarkan. $600 \mathrm{ml}$ air didihkan, kemudian kunyit yang telah dimemarkan dimasukkan selama \pm 10 menit. Air hasil rebusan kunyit didiamkan hingga dingin kemudian disaring dan disimpan dalam bak penampung.

Penelitian menggunakan Rancangan Acak Lengkap (RAL), dengan 5 perlakuan dan 5 ulangan, tiap ulangan terdapat 8 ekor ayam broiler. Adapun perlakuan yang diberikan yaitu : $\mathrm{T} 0=$ air minum tanpa air rebusan kunyit (kontrol), $\mathrm{T} 1=$ pemberian $25 \%$ air rebusan kunyit : $75 \%$ air minum, $\mathrm{T} 2=$ pemberian $50 \%$ air rebusan kunyit : $50 \%$ air minum, $\mathrm{T} 3=$ pemberian $75 \%$ air rebusan kunyit : $25 \%$ air minum dan T4= pemberian $100 \%$ air rebusan kunyit. Air minum diberikan secara ad libitum maka konsumsi air minum diukur dan dicatat setiap hari.

Pakan yang digunakan pada penelitian ini yaitu pakan komersial dari PT. Charoen Pokphand Indonesia periode starter (1-21 hari) B-11S dan periode finisher (21-35 hari) BR-1AJ disajikan pada Tabel 1. Pakan diberikan secara ad libitum maka konsumsi pakan diukur dan dicatat setiap hari.
Penimbangan bobot badan dilakukan setiap seminggu sekali. Pengambilan data bobot relatif dilakukan dengan menimbang bobot badan akhir, bobot dan panjang tembolok, proventikulus, ventrikulus, duodenum, jejenum, ileum, usus besar, sekum, hati dan pankreas. Bobot relatif dan panjang relatif saluran pencernaan ditentukan dengan rumus:

$$
\frac{\text { bobot atcu panjang organ }}{\text { bobot hidup }} \times 100 \%
$$

Konversi pakan dihitung dengan rumus:

$$
\frac{\text { jumlah pakan yang dikonsumsi }}{\text { bobat hidup }}
$$

\section{HASIL DAN PEMBAHASAN}

\section{Pengaruh Air Rebusan Kunyit terhadap Bobot Relatif dan Panjang Relatif Saluran Pencernaan Ayam Broiler}

Data konsumsi air minum, konsumsi pakan, bobot hidup, konversi pakan, bobot relatif dan panjang relatif saluran pencernaan ayam broiler umur 35 hari dengan pemberian air rebusan kunyit dalam air minum disajikan pada Tabel 2.

Berdasarkan data penelitian pada Tabel 2, konsumsi air minum, konsumsi pakan, bobot hidup dan konversi pakan tidak memberikan pengaruh nyata. Semakin tinggi jumlah pakan yang dikonsumsi maka semakin tinggi pula tingkat konsumsi air minumnya (Rasyaf, 2008). Dalam penelitian ini konsumsi pakan sama sehingga konsumsi air minum juga sama. Konsumsi air minum dipengaruhi pula oleh jenis ayam, aktivitas ayam, dan lingkungan dimana dalam penelitian ini semuanya juga sama. Konsumsi pakan yang sama disertai 
Tabel 2. Pengaruh perlakuan terhadap konsumsi air minum, konsumsi pakan, bobot hidup, konversi pakan, bobot relatif dan panjang relatif saluran pencernaan umur 35 hari.

\begin{tabular}{lccccc}
\hline Variabel & $\mathrm{T} 0$ & $\mathrm{~T} 1$ & $\mathrm{~T} 2$ & $\mathrm{~T} 3$ & $\mathrm{~T} 4$ \\
\hline Konsumsi Air & $4512,25 \pm 196,55$ & $4120,24 \pm 219,21$ & $4461,20 \pm 100,42$ & $4460,43 \pm 218,43$ & $4427,60 \pm 441,41$ \\
Minum (ml/ekor) & & & & & \\
Konsumsi Pakan & $2493,90 \pm 57,18$ & $2502,61 \pm 85,90$ & $2560,49 \pm 82,11$ & $2590,01 \pm 83,47$ & $2552,40 \pm 130,93$ \\
(g/ekor) & $1478 \pm 101,22$ & $1470 \pm 173,31$ & $1501 \pm 97,30$ & $1658 \pm 173,55$ & $1418,20 \pm 93,88$ \\
Bobot Hidup (gr) & $1,69 \pm 0,13$ & $1,72 \pm 0,21$ & $1,71 \pm 0,09$ & $1,58 \pm 0,18$ & $1,81 \pm 0,19$ \\
Konversi Pakan & & & & \\
Bobot Relatif & $0,28 \pm 0,07$ & $0,30 \pm 0,05$ & $0,28 \pm 0,04$ & $0,25 \pm 0,04$ & $0,30 \pm 0,04$ \\
Tembolok (\%) & $0,43 \pm 0,15$ & $0,46 \pm 0,11$ & $0,42 \pm 0,10$ & $0,50 \pm 0,06$ & $0,53 \pm 0,10$ \\
Proventrikulus (\%) & $1,22 \pm 0,21$ & $1,18 \pm 0,24$ & $1,11 \pm 0,16$ & $1,06 \pm 0,22$ & $1,15 \pm 0,29$ \\
Ventrikulus (\%) & $0,73 \pm 0,05$ & $0,71 \pm 0,05$ & $0,73 \pm 0,02$ & $0,72 \pm 0,08$ & $0,78 \pm 0,08$ \\
Duodenum (\%) & $0,85 \pm 0,20$ & $0,99 \pm 0,10$ & $1,08 \pm 0,28$ & $0,88 \pm 0,14$ & $0,87 \pm 0,14$ \\
Jejenum (\%) & $0,65 \pm 0,17$ & $0,89 \pm 0,06$ & $0,63 \pm 0,22$ & $0,76 \pm 0,22$ & $0,74 \pm 0,22$ \\
Ileum (\%) & $0,29 \pm 0,04^{\mathrm{a}}$ & $0,35 \pm 0,04^{\mathrm{ab}}$ & $0,41 \pm 0,06^{\mathrm{b}}$ & $0,26 \pm 0,08^{\mathrm{a}}$ & $0,33 \pm 0,12^{\mathrm{ab}}$ \\
Sekum (\%) & $0,10 \pm 0,01$ & $0,10 \pm 0,01$ & $0,13 \pm 0,04$ & $0,09 \pm 0,01$ & $0,11 \pm 0,05$ \\
Usus Besar (\%) & $2,52 \pm 0,20$ & $2,55 \pm 0,50$ & $2,41 \pm 0,44$ & $2,36 \pm 0,39$ & $2,53 \pm 0,28$ \\
Hati (\%) & $0,19 \pm 0,01^{\mathrm{a}}$ & $0,20 \pm 0,04^{\mathrm{a}}$ & $0,13 \pm 0,01^{\mathrm{a}}$ & $0,11 \pm 0,02^{\mathrm{b}}$ & $0,10 \pm 0,03^{\mathrm{b}}$ \\
Pankreas (\%) & & & & \\
Panjang Relatif & $2,01 \pm 0,30^{\mathrm{a}}$ & $1,79 \pm 0,06^{\mathrm{a}}$ & $1,88 \pm 0,20^{\mathrm{a}}$ & $1,61 \pm 0,12^{\mathrm{b}}$ & $1,74 \pm 0,16^{\mathrm{ab}}$ \\
Duodenum (\%) & $5,08 \pm 1,05$ & $4,95 \pm 0,47$ & $4,58 \pm 0,89$ & $4,46 \pm 0,66$ & $5,14 \pm 0,66$ \\
Jejenum (\%) & $3,89 \pm 0,43^{\mathrm{a}}$ & $4,60 \pm 0,45^{\mathrm{a}}$ & $3,39 \pm 0,87^{\mathrm{b}}$ & $3,68 \pm 0,45^{\mathrm{b}}$ & $4,51 \pm 0,327^{\mathrm{a}}$ \\
Ileum (\%) & $0,92 \pm 0,19$ & $1,14 \pm 0,08$ & $1,15 \pm 0,10$ & $1,04 \pm 0,32$ & $1,28 \pm 0,38$ \\
Sekum (\%) & $0,47 \pm 0,07$ & $0,53 \pm 0,11$ & $0,42 \pm 0,03$ & $0,41 \pm 0,05$ & $0,47 \pm 0,04$ \\
Usus Besar (\%) & & & & \\
\hline Ket: Sup & & & & \\
\hline
\end{tabular}

Ket: Superskrip yang berbeda pada kolom yang sama menunjukkan perbedaan nyata $(\mathrm{P}<0,05)$

genetik ayam broiler yang sama menghasilkan bobot badan akhir umur 35 hari yang sama. Menurut Lacy dan Vest (2000) faktor utama yang mempengaruhi konversi pakan adalah genetik, ventilasi, sanitasi, kualitas pakan, jenis pakan, penggunaan zat aditif, kualitas air, penyakit dan pengobatan serta manajemen pemeliharaan. Dalam penelitian ini semua faktor tersebut sama kecuali zat aditif yang diberikan adalah air rebusan kunyit yang diberikan dalam air minum. Hasil penelitian ini sama dengan hasil penelitian Khumaini (2012) dimana konsumsi pakan, bobot hidup dan konversi pakan dengan pemberian air kunyit tidak memberikan pengaruh yang nyata.

Berdasarkan Tabel 2. penambahan air rebusan kunyit dalam air minum berpengaruh nyata $(\mathrm{P}<0,05)$ terhadap bobot relatif sekum dan pankreas dan panjang relatif duodenum dan ileum. Hasil analisis ragam masingmasing menunjukkan bahwa penambahan air rebusan kunyit dengan pemberian 25\% air rebusan kunyit dalam air minum terhadap bobot relatif sekum dan pankreas serta panjang relatif duodenum dan ileum sama dengan kontrol (tanpa pemberian air rebusan kunyit). Pemberian air rebusan kunyit dalam air minum dalam taraf $50-100 \%$ justru menurukan bobot relatif sekum dan pankreas serta panjang relatif duodenum. Purwanti (2008) juga menemukan bahwa pemberian kunyit mengakibatkan penurunan bobot relatif usus halus dan sekum ayam broiler umur 35 hari. Tidak adanya pengaruh dari rebusan air kunyit dalam penelitian ini dan penelitian lainnya diduga karena air rebusan kunyit yang diberikan tidak dalam keadaan segar (disimpan terlebih dahulu) dimana zat aktif dalam air kunyit menurun dan mengalami oksidasi yang dapat berefek negatif (Samarasinghe, 2003; Ketron et al., 2013). Selain itu Pratikno (2010) juga menemukan bahwa pemberian kunyit dengan taraf pemberian diatas $50 \%$ pada ayam broiler tidak memberikan pengaruh karena kandungan kurkumin dalam 
kunyit tidak dapat terabsorpsi secara efektif oleh sel epitelium intestinum, sehingga tidak dapat mempengaruhi metabolisme saluran pencernaan.

\section{KESIMPULAN}

Penambahan air rebusan kunyit dalam air minum menurunkan bobot relatif sekum dan pankreas serta panjang relatif duodenum, maka dianjurkan untuk tidak menggunakan air rebusan kunyit dalam air minum.

\section{DAFTAR PUSTAKA}

Chattopadhyay I., K. Biswas dan U. Bandyopadhyay. 2004. Turmeric and Curcumin: Biological Actions and Medicinal Applications. Review Article. Current Science. 87 (1) : 44-53.

Dono, N. D. 2013. Turmeric (Curcuma longa linn.) supplementations analternative to antibiotics in poultry diets. Wartazoa. 23 (1) : 41-49.

Hutabarat, H., J. M. Sihombing, M. Siregar dan H. Saragih. 2014. Pengaruh Pemberian, Tepung Kunyit dan Tepung Temulawak dalam Ransum terhadap Performans, Persentase Lemak Abdominal, Kolesterol Daging dan Darah Ayam Broiler. Fakultas Peternakan, Universitas HKBP Nommensen, Medan. (Tesis).

Ketron, A. C., O. N. Gordon, C. Schneider and N. Osheroff. 2013. Oxidative metabolites of curcumin poison human type II topoisomerases. Biochemistry 52 (1) : 221-227.

Khumaini, A., R. E. Mudawaroch dan D.A.
Hanung. 2012. Pengaruh penambahan sari kunyit (Curcuma domestica val) dalam air minum terhadap konsumsi pakan dan konsumsi air minum ayam broiler. Surya Agritama 1 (2) : 85-93.

Lacy, M. and L. R. Vest. 2000. Improving Feed Convertion in Broiler : A Guide for Growers. Springer Science and Business Media Inc, New York.

Mario, W. L. M. S., E. Widodo dan O. Sjofjan.2013. Pengaruh penambahan kombinasi tepung jahe merah, kunyit dan meniran dalam pakan terhadap kecernaan zat makanan dan energi metabolis ayam pedaging. JIIP 24 (1) : $1-8$.

Murwani, R. 2010. Broiler Modern. Widya Karya, Semarang.

Pratikno, H. 2010. Pengaruh ekstrak kunyit (Curcuma dimestica vahl.) terhadap bobot badan ayam broiler (Gallus sp.). Buletin Anatomi dan Fisiologi. 18 (2) : 39-46.

Purwanti, S. 2008. Kajian Efektifitas Pemberian Kunyit, Bawang Putih dan Mineral Zink terhadap Performa, Kadar Lemak, Kolesterol dan Status Kesehatan Broiler. Sekolah Pascasarjana, Institut Pertanian Bogor, Bogor. (Tesis).

Rasyaf, M. 2008. Produksi dan Penambahan Ransum Unggas. Kanisius, Yogyakarta.

Samarasinghe, K., C. Wenk, K. S. F. T. Silva and J. M. D. M. Gunasekera. 2003. Turmeric (Curcuma longa) root powder and mannanoligosaccharides as alternative to antibiotic in broiler chicken diet. Asian-aust. J. Anim. Sci.16 (10) : 1495 -1500. 